\title{
TOLERANCE OF UNCERTAINTY AND AMBIGUITY OF THE SITUATION AND ANXIETY AS A STATE AND AS A FEATURE
}

\author{
SYLWIA BOKUNIEWICZ \\ Institute of Pedagogy, Faculty of Historical and Pedagogical Sciences \\ University of Wroclaw, ul. Dawida 1, 50-527 Wrocław, Poland \\ E-mail address: 257525@uwr.edu.pl \\ ORCID: https://orcid.org/ 0000-0002-0378-5136
}

\begin{abstract}
Aim. The aim of the undertaken research is to explain to what extent the tolerance of uncertainty and ambiguity of the situation is associated with anxiety as a state and with anxiety as a trait.

Methods. The survey was conducted in electronic form with the aid of a form created on the Profitest.pl platform. The Uncertainty Tolerance Scale (own translation), COPE, STAI and Ambiguity tolerance scale were used. The examined variables were: coping with stress, feeling of anxiety as a state and anxiety as a trait (explained variables); uncertainty tolerance and ambiguity tolerance (explanatory variables).

Results and conclusion. The research shows that people who feel anxious in uncertainty situations can absorb it and start using it as a trait. It was also noted that the greater the tolerance of uncertainty they have to reply to, the worse they cope in critical ambiguity situations. It has also been found that in order to overcome discomfort in difficult situations, people use equal coping strategies. Greater ambiguity tolerance allows participants to experience less stress. On the other hand, the lower the tolerance, the more often they reach for emotional and instrumental support and focus on emotions.

Originality. Understanding the mediating processes related to the studied phenomenon may be of fundamental importance in the development of support systems promoting the improvement of mental functioning of people who have problems with quick adaptation to changes and in the creation of appropriate prevention programs aimed at helping these people.

Key words: tolerance of ambiguity, anxiety as a state, anxiety as a trait, tolerance of uncertainty, coping with stress
\end{abstract}

\section{INTRODUCTION}

The aim of the undertaken research is to explain to what extent the tole1 rance of uncertainty and ambiguity of a situation is related to anxiety as a state and to anxiety as a trait. This is an important question because this type

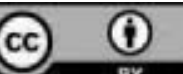


of research has not yet been conducted, and its results may provide interesting cognitive conclusions. Based on the analysis of literature, which I will present in the further part of this paper, I assume that the manifested tolerance to uncertainty and ambiguity correlates with anxiety as a state and as a trait. Another conclusion is that people with a high tolerance to uncertainty function well in ambiguous situations, and that the subjects who are good at tolerating uncertainty and ambiguity in order to reduce the discomfort (stress) associated with uncertainty and ambiguity use various strategies.

\section{TOLERANCE OF UNCERTAINTY}

According to Jerome Kagan (1972, as cited in: Kossowska, 2009), uncertainty is an important dimension of human existence. It is defined as an inability to predict future events, as well as an incompatibility within and between cognitive structures and behaviour or experience.

Making a choice in a given situation is almost always accompanied by uncertainty. According to Zygmunt Bauman (2007), in the description of the postmodern reality in which we currently operate, volatility, uncertainty and fluidity are terms that are often combined.

People, feeling insecure, try to take action to lower the uncertainty level and make sure that they are trying to do whatever it takes to do so. This is because it is impossible to act in the event of unpredictability. For this reason, uncertainty could be considered cultural problem. Treating uncertainty as an element of cultural heritage, which is passed on and strengthened by the family, the state and the school, one can say that one takes it from his environment. Uncertainty is instilled by others or through socialization. Each society is characterized by its own specific ways of dealing with the sense of insecurity and the associated sense of anxiety and danger by its members in the face of unknown, unpredictable and new situations (Hofstede and Hofstede, 2007).

Uncertainty can be analysed in two dimensions: individual, where the attention of the individual focuses on subjective perception and, at the same time, on responding to unclear situations; and collective, where avoiding uncertainty in a given society is an important cultural dimension.

Daniel Kahneman and Amos Tversky (1982) distinguish two types of uncertainty: internal (depending on the person) and external (independent of the person). Internal uncertainty concerns the state of knowledge of a given person, e.g. connected with the necessity of taking appropriate action (or not), and thus the influence on the realization of a task, on its result. In turn, external uncertainty concerns the individual who has no influence on the outcome, e.g. on the outcome of a draw (Kahneman \& Tversky, 1982). According to Kahneman and Tversky (1982), the external uncertainty can be divided into single and distributional, and the internal uncertainty - into argued and experienced. Uncertainty, given the knowledge of opportunity, can also be divided into known, unknown and unknowable uncertainty (Chua Chow \& Sarin, 2002). It 
should be pointed out that during the analysis of the literature on the subject, the terms risk and uncertainty may be used interchangeably. Known uncertainty can be understood as classically understood risk - it refers to the situation when the probability failure or success is known. Another situation occurs when the chances are not known - then one can speak about the unknown uncertainty. When no one knows the probability, one has to do with the unrecognizable uncertainty.

Ryszard Studenski (2004) is of the opinion that the feeling of uncertainty is created by information deficit, unpredictability, ambiguity. According to Studenski (2004), the tolerance of uncertainty together with a high level of aspirations, nonconformism, the need for achievements and the tendency to competitive behaviour correlates positively with the tendency to take a risk. The same author, when defining the ability to take a risk, pointed out that

"in everyday situations we are exposed to various threats and risks. By taking risks, we create an opportunity for success, but we also risk failure. By refraining from risk, we avoid failure, but we also do not get what is 'to take'. We usually have to get on the trains that are leaving for success. This does not mean that we have to do it at any speed. Getting on an over-speed train can be too risky, especially for those who like speed, but do not have the experience to assess the type of train, direction and efficiency needed to get on. Sometimes it is safer to wait for the next train if you are sure that the departing train is not the last and that it is actually going too fast. We run the risk both when getting on and off and when we decide to wait for a better opportunity" (Studenski, 2004, p. 13).

As society develops, the area of unclear, unpredictable and uncertain situations that require risky decisions is growing. It is worth noting that not all people are able to cope with such a change, and who are helpless, unable to find themselves in new, unknown conditions, passive, and unable to cope with the inevitable changes (Jacyno, 2007). Hence, the conclusion is that new ways of dealing with the unpredictability and ambiguity of reality should be identified and distinguished.

\section{UNCERTAINTY - MANAGMENT STRATEGY}

As Bożena Majerek states: "in various spheres of everyday life (health, family, friends, acquaintances, work, housing, education, leisure time) people experience uncertainty, fragility or lack of sense of doing things" (Majerek, 2018, p. 8).

Uncertainty related to the situation or the problem posed may evoke various reactions, which depend on the individual characteristics of the person. One of the reactions may be resistance. Shaul Oreg (2003) points out that in a situation of uncertainty he is triggered by such features as: the search for routine, stiffness of the learner, emotional reaction to an imposed change, for which the individual was not ready. According to Connie R. Wanberg and Joseph 
T. Banas, such traits as optimism, mental resilience and self-esteem are connected with readiness to change and struggling with uncertainty (Oreg, 2003). Robert Wayne Edwards (2003) points out that the feature of openness to experience and resistance to change are at the two ends of the continuum. Openness to change correlates positively with tolerance for ambiguity, searching for impressions, openness to experience, aversion to risk. In turn, it negatively correlates with extraversion, neuroticism and dogmatism.

Individuals differ in how they respond to uncertainty and unpredictability. A person with a high tolerance to uncertainty will interpret any difficult situation as a challenge, while a low tolerance to uncertainty will make him consider it a threat (Dalbert, 1999). The theory of styles of responding to uncertainty indicates two types of reactions: active coping, which is characteristic of people who tolerate uncertainty well, who take action to remove or eliminate uncertainty by seeking information, trying to explain; and avoidance, which is characteristic of people oriented towards uncertainty, who avoid uncertain situations by engaging in activities unrelated to uncertainty (Sorrentino, Hudson, \& Huber, 2005). Also, a sense of humour is helpful in dealing with difficult situations related to insecurity. It gives an opportunity to neutralize or prevent sadness or fear associated with a difficult situation. Robert McCrae and Paul Costa (1986) consider humour to be one of the techniques for dealing with difficult situations.

Unpredictability and ambiguity are related to the uncertainty that one meets every day. These are difficult situations, which are marked by the risk of unfavourable or threatening consequences. Małgorzata Kossowska's research (2005) shows that tolerance of uncertainty has a protective effect in difficult and threatening situations. Persons who tolerate uncertainty well value difficult situations positively, are more positive towards themselves and others, are more satisfied with life and, at the same time, better evaluate their own effectiveness.

A person can never be sure whether the activity or decision they have taken is the right one, because uncertainty is an inherent element of the environment in which we function (Kozielecki, 1977). The feeling of uncertainty is commonly associated with anxiety, disorientation, nervousness, the source of which is ignorance, lack of certainty of the information we possess, contradictions that appear, etc. (Zaleśkiewicz, 2005).

\section{TOLERANCE OF AMBIGUITY}

Ambiguity differs from uncertainty in that, under conditions of ambiguity, we evaluate a situation in order to react to it appropriately. In turn, uncertainty is the result of our reaction to a given situation.

According to Stanley Budner, uncertainty tolerance is "the tendency to perceive (interpret) ambiguous situations as desirable", and the intolerance of uncertainty is "the tendency to perceive (interpret) ambiguous situations as 
sources of danger" (Budner, 1962, p. 29). The author treats situations of ambiguity as those in which, due to the lack of sufficient data, it is not possible to categorize and structure it. Budner gives three types of such situations: new, in which we have no indications and do not know how to react; complex, in which there are many indications and possible reactions, and social situations in which indications do not help in obtaining the expected solution. In contrast, Hans Eysenck (1954) believes that uncertainty tolerance is itself a definition and applies it to cognitive rigidity.

Else Frenkel-Brunswik (1949) defines ambiguity intolerance as the difficulty for a person to recognise positive and negative features in relation to the same object. People who are characterized by ambiguity intolerance tend to apply extreme solutions, deny reality, displaced ambiguous aspects of experience, prematurely formulated value judgements. Their social behaviour is conventional, and they have a positive attitude towards institutions controlling the flow of information - in a word, they seek certainty and unambiguity (Budner, 1962).

The test person is exposed to an unpleasant state of mental tension, when they are in a difficult situation that causes uncertainty. Therefore, he or she applies various strategies to remove the unpleasant condition. Therefore, it seems reasonable to use the strategies selected by people in a stressful situation (seeking instrumental support, active coping, seeking emotional support, avoiding competitive actions, planning, turning to religion, positive re-evaluation and development, refraining from acting, acceptance, concentration and discharge of emotions, denial, distraction, cessation of activities, use of alcohol or other psychoactive substances, sense of humour; Carver, Scheier, \& Weintraub 2009), and to determine what strategies people use to reduce the discomfort associated with a situation of uncertainty.

\section{COPING WITH STRESS}

A stressful situation requires that you react to it in some way. There are various types of stress management typologies. For example, Richard S. Lazarus (1993) states that a given situation generates certain human behaviour as a conscious action and interaction of various coping strategies. In his opinion, there are two ways of coping with stressful situations: (1) task-oriented and (2) focused on reducing emotional tension.

In contrast, James D. Parker and Norman S. Endler (1992) distinguish several forms of reducing emotional tension such as, for example, avoidance, which consists of: a style that focuses on taking an action to solve a problem or change a situation (when one uses various cognitive processes); the emotion-focused style (when one does not take action to solve the situation, and only wants to minimize or even remove the causes of a stressful situation, but above all, focuses on reducing emotional tension); the avoidance-focused style (when one rejects thoughts about problems, dealing with other things, e.g. shopping, cleaning, socializing, etc.). 


\section{ASSUMPTIONS AND RESEARCH TOOLS USED}

H1: Uncertainty tolerance is strongly related to anxiety as a trait and weakly to anxiety as a state.

$\mathrm{H} 2$ : The tolerance of ambiguity is strongly associated with the drug as a trait and weakly associated with anxiety as a condition.

H3: Individuals with high uncertainty and ambiguity tolerance have different strategies for dealing with stress.

H4: Persons with a high tolerance of uncertainty are good at dealing with ambiguity situations.

- Uncertainty tolerance scale Claudia Dalbert (translation);

- COPE - multidimensional inventory to measure stress management in adaptation of Zygrfyd Juczyński, Nina Ogińska-Bulik;

- Ambiguity tolerance scale Edward F. Mcquarri and David G. Mick in Polish adaptation;

- STAI - State and Fear Inventory STAI Charles D. Spielberger, Richard L. Gorsuch, Robert E. Lushene in Polish adaptation.

\section{METHOD}

A survey was conducted electronically on the Profitest.pl platform. IBM SPSS Statistics version 25 was used for the statistical analysis. It allowed for basic descriptive statistics and correlation analysis with Pearson's $r$ coefficient. $\mathrm{P}<0.05$ was adopted as the level of statistical significance.

The examined variables were: dealing with stress, feeling of anxiety as a state and anxiety as a trait (explained variables); uncertainty tolerance and ambiguity tolerance (explaining variables). It is worth noting that these are correlation studies, so the relationship could have been reversed.

This can be seen as a premise for further research on uncertainty and ambiguity tolerance and anxiety as a trait and as a state. The respondents were also asked for information on gender, age, education, marital status and place of residence.

\section{CHARACTERISTICS OF THE PERSONS SURVEYED}

210 people participated in the survey. There were 180 women $(85.7 \%)$ and 30 men $(14.3 \%)$. The respondents were people from 19 to 65 years old (M $=27 ; \mathrm{SD}=7.07)$, mainly unmarried $(30.8 \%)$, married $(28.9 \%)$ and people in informal relationships (40,3\%). Most of the respondents had higher education (58.8\%), were students (19.4\%) or had secondary education $(18.5 \%) .64 .5 \%$ of the respondents lived in a city with over 150,000 residents. 


\section{THE SURVEY PROCEDURE}

The survey was conducted using the online form at Profitest.pl platform from 4 to 23 June 2020. The form contained the information about the author and the purpose of the survey, ensuring the anonymity of the respondents. Study participants were asked to complete questionnaires, including demographic data. Respondents were invited to the study via a link to the survey among the study's associates and on Facebook discussion groups.

\section{RESULTS}

In order to answer the research questions and test the hypotheses raised, statistical analyses were carried out using IBM SPSS Statistics version 25, which was used to analyse basic descriptive statistics and correlation with Pearson's $r$ coefficient.

Basic descriptive statistics of the measured quantitative variables together with a Kolmogorov-Smirnov test

Basic descriptive statistics and the Kolmogorov-Smirnov test were calculated, which test the normality of the distribution of variables on a quantitative scale. They show that the distribution of anxiety as a state (STAI), ambiguity tolerance, uncertainty tolerance, and three stress coping factors (active coping, avoidance behaviours, as well as seeking support and focus on emotions) is similar to the normal distribution. Other variables have a distribution distant from the Gaussian curve, but the skewness values of these variables do not exceed the absolute value of 2 . This means that their distribution is slightly skewed, which makes it possible to use parametric tests in order to verify research hypotheses. Basic descriptive statistics and tests of normality of distribution are presented in Table 1.

Table 1

Basic descriptive statistics with the Kolmogorov-Smirnov test

\begin{tabular}{cccccccccc}
\hline & $\mathrm{M}$ & $\mathrm{Me}$ & $\mathrm{SD}$ & $\mathrm{Sk}$ & Kurt. & Min. & Maks. & K-S & $\mathrm{p}$ \\
\hline $\begin{array}{c}\text { Trait anxiety } \\
\text { (STAI) }\end{array}$ & 47,1429 & 45 & 11,77332 & 0,331 & $-0,635$ & 24 & 74 & 0,086 & $.001 \mathrm{c}$ \\
$\begin{array}{c}\text { State anxiety } \\
\text { (STAI) }\end{array}$ & 50,0952 & 49 & 10,22103 & 0,173 & $-0,434$ & 26 & 76 & 0,058 & $.087 \mathrm{c}$ \\
$\begin{array}{c}\text { Tolerance of } \\
\text { ambiguity }\end{array}$ & 54,7095 & 55 & 7,68559 & 0,045 & 0,371 & 35 & 81 & 0,064 & $.038 \mathrm{c}$ \\
$\begin{array}{c}\text { Tolerance of } \\
\text { uncertainty } \\
\quad \text { COPE }\end{array}$ & 28,9524 & 28,5 & 5,76722 & 0,084 & 0,377 & 10 & 45 & 0,068 & $.019 \mathrm{c}$ \\
$\begin{array}{c}\text { Active coping } \\
\text { (n) }\end{array}$ & 2,8262 & 2,75 & 0,48559 & $-0,089$ & 0,337 & 1,5 & 4 & 0,138 & $.000 \mathrm{c}$
\end{tabular}


Journal of Education Culture and Society No. 2_2020

\begin{tabular}{|c|c|c|c|c|c|c|c|c|c|}
\hline Planning & 2,869 & 3 & 0,68003 & $-0,373$ & $-0,022$ & 1 & 4 & 0,114 & $.000 \mathrm{c}$ \\
\hline $\begin{array}{l}\text { Looking for } \\
\text { instrumental } \\
\text { support }\end{array}$ & 2,919 & 3 & 0,75655 & $-0,729$ & 0,171 & 1 & 4 & 0,138 & $.000 \mathrm{c}$ \\
\hline $\begin{array}{l}\text { Looking for } \\
\text { emotional } \\
\text { support }\end{array}$ & 2,9155 & 3 & 0,89606 & $-0,479$ & $-0,756$ & 1 & 4 & 0,129 & $.000 \mathrm{c}$ \\
\hline $\begin{array}{l}\text { Avoiding } \\
\text { competing } \\
\text { activities }\end{array}$ & 2,5857 & 2,5 & 0,63991 & $-0,002$ & $-0,187$ & 1 & 4 & 0,091 & $.000 \mathrm{c}$ \\
\hline $\begin{array}{l}\text { Return to } \\
\text { religion }\end{array}$ & 1,9119 & 1,5 & 1,03352 & 0,823 & $-0,728$ & 1 & 4 & 0,21 & $.000 \mathrm{c}$ \\
\hline $\begin{array}{l}\text { Positive reva- } \\
\text { luation }\end{array}$ & 2,9262 & 3 & 0,65112 & $-0,456$ & $-0,106$ & 1 & 4 & 0,108 & $.000 \mathrm{c}$ \\
\hline $\begin{array}{l}\text { Refraining } \\
\text { from acting }\end{array}$ & 2,5929 & 2,625 & 0,52138 & $-0,261$ & 0,379 & 1 & 4 & 0,118 & $.000 \mathrm{c}$ \\
\hline Acceptance & 2,5833 & 2,75 & 0,65819 & $-0,156$ & $-0,013$ & 1 & 4 & 0,135 & $.000 \mathrm{c}$ \\
\hline $\begin{array}{c}\text { Focusing on } \\
\text { emotions }\end{array}$ & 3,0155 & 3 & 0,69778 & $-0,35$ & $-0,727$ & 1,25 & 4 & 0,113 & $.000 \mathrm{c}$ \\
\hline Denial & 1,7619 & 1,75 & 0,62626 & 0,88 & 0,725 & 1 & 4 & 0,141 & $.000 \mathrm{c}$ \\
\hline Distraction & 2,3762 & 2,25 & 0,62458 & $-0,008$ & $-0,392$ & 1 & 4 & 0,104 & $.000 \mathrm{c}$ \\
\hline $\begin{array}{l}\text { Discontinu- } \\
\text { ation of acti- } \\
\text { vities }\end{array}$ & 1,8786 & 2 & 0,66041 & 0,662 & 0,165 & 1 & 4 & 0,137 & $.000 \mathrm{c}$ \\
\hline $\begin{array}{l}\text { Use of alco- } \\
\text { hol or other } \\
\text { means }\end{array}$ & 1,7012 & 1,25 & 0,91978 & 1,078 & $-0,106$ & 1 & 4 & 0,272 & $.000 \mathrm{c}$ \\
\hline $\begin{array}{l}\text { Using a sense } \\
\text { of humor }\end{array}$ & 1,9857 & 2 & 0,81978 & 0,558 & $-0,556$ & 1 & 4 & 0,134 & $.000 \mathrm{c}$ \\
\hline Active coping & 2,76 & 2,75 & 0,43775 & $-0,195$ & 0,411 & 1,4 & 3,85 & 0,073 & $.009 \mathrm{c}$ \\
\hline $\begin{array}{l}\text { Evasive beha- } \\
\text { viour }\end{array}$ & 2,0478 & 2 & 0,43573 & 0,645 & 1,182 & 1,08 & 4 & 0,062 & $.046 \mathrm{c}$ \\
\hline $\begin{array}{l}\text { Seeking sup- } \\
\text { port and con- } \\
\text { centrating on } \\
\text { emotions }\end{array}$ & 2,6905 & 2,75 & 0,62338 & $-0,27$ & $-0,386$ & 1,13 & 4 & 0,06 & $.064 \mathrm{c}$ \\
\hline
\end{tabular}

\footnotetext{
Note: M - average; Me - median; SD - standard deviation; Sk. - skewness; Kurt. - kurtosis; Min and Max - the lowest and highest distribution value; K-S - Kolmogorov Smirnov test result; $\mathrm{p}$ - Relevance.
}

Source: own research. 
Tolerance of uncertainty and tolerance of ambiguity and anxiety as a feature and as a state

In the next stage of the analysis, it was decided to investigate whether and how the uncertainty tolerance and the ambiguity tolerance are related to anxiety as a feature and as a condition. To this end, correlation analyses with Pearson's $r$-factor were performed. As it turns out, the uncertainty tolerance does not co-exist with anxiety as a trait and as a state. However, a statistically significant correlation between anxiety as a trait and anxiety as a state was observed. This correlation is very high and positive. This proves that the amount of anxiety as a trait increases with the feeling of anxiety as a state. A low and negative correlation between the uncertainty tolerance and the ambiguity tolerance was also observed. This means that the greater the uncertainty tolerance of the respondents, the worse they cope with ambiguity situations. No correlation between the ambiguity tolerance and anxiety as a condition and anxiety as a trait has been noted. The results of the analyses discussed are presented in Table 2.

Table 2

The relationship between the uncertainty and ambiguity tolerance and anxiety as a state and as a trait

\begin{tabular}{lccccc}
\hline & & $\begin{array}{c}\text { State anxiety } \\
(\mathrm{STAI})\end{array}$ & $\begin{array}{c}\text { Trait anxiety } \\
(\mathrm{STAI})\end{array}$ & $\begin{array}{c}\text { Tolerance of } \\
\text { uncertainty }\end{array}$ & $\begin{array}{c}\text { Tolerance of } \\
\text { ambiguity }\end{array}$ \\
\hline State anxiety & $\mathrm{r}$ Pearson & 1 & $.810^{* *}$ & .128 & .016 \\
(STAI) & elevance & & .000 & .063 & .816 \\
Trait anxiety & $\mathrm{r}$ Pearson & $.810^{* *}$ & 1 & .082 & .093 \\
(STAI) & Relevance & .000 & & .237 & .178 \\
Tolerance of & $\mathrm{r}$ Pearson & .128 & .082 & 1 & $-.236^{* *}$ \\
uncertainty & Relevance & .063 & .237 & & .001 \\
Tolerance of & $\mathrm{r}$ Pearson & .016 & .093 & $-.236^{* *}$ & 1 \\
ambiguity & Relevance & .816 & .178 & .001 & \\
Note: ** Significant correlation at 0.01 (two-sided). & & \\
Source: own research. & \multicolumn{5}{l}{}
\end{tabular}

Tolerance of uncertainty and tolerance of ambiguity and coping with stress

In the next step, the relationship between uncertainty and ambiguity tolerance and stress management strategies was considered. For this we need an analogous correlation analysis with the Pearson player. The results of these analyzes are visible from the line with the uncertainty tolerance. It is related to the search for support for instrumental exploration and the search for support and concentration on emotions. All these relationships are weak and negative. It results from the fact that with the intensification of uncertainty tolerance, the respondents will less often choose the search for emotional support, instrumental support and concentration on emotions as ways of dealing with the feeling of uncertainty. On the other hand, the tolerance of ambiguity correlates weakly and positively with distraction. It can be concluded that people with 
Journal of Education Culture and Society No. 2_2020

high ambiguity tolerance most often choose distraction as their coping strategy. Table 3 shows the results of these correlation analyses.

Table 3

The relationship between uncertainty and ambiguity tolerance and stress management strategies

\begin{tabular}{|c|c|c|c|}
\hline & & $\begin{array}{l}\text { Tolerance of } \\
\text { uncertainty }\end{array}$ & $\begin{array}{c}\text { Tolerance of } \\
\text { ambiguity }\end{array}$ \\
\hline \multirow[t]{2}{*}{ Active coping } & r Pearson & $-0,115$ & $.173^{*}$ \\
\hline & Relevance & 0,096 & 0,012 \\
\hline \multirow[t]{2}{*}{ Planning } & r Pearson & $-0,072$ & 0,082 \\
\hline & Relevance & 0,297 & 0,237 \\
\hline \multirow{2}{*}{$\begin{array}{l}\text { Looking for } \\
\text { instrumental support }\end{array}$} & r Pearson & $-.241^{* *}$ & $.179 * *$ \\
\hline & Relevance & 0,000 & 0,009 \\
\hline \multirow{2}{*}{$\begin{array}{l}\text { Looking for emotional } \\
\text { support }\end{array}$} & r Pearson & $-.228^{* *}$ & $.194^{* *}$ \\
\hline & Relevance & 0,001 & 0,005 \\
\hline \multirow{2}{*}{$\begin{array}{l}\text { Avoiding competing } \\
\text { activities }\end{array}$} & r Pearson & $-.160^{*}$ & $.149 *$ \\
\hline & Relevance & 0,020 & 0,031 \\
\hline \multirow[t]{2}{*}{ A return to religion } & r Pearson & $-0,053$ & $-0,021$ \\
\hline & Relevance & 0,446 & 0,759 \\
\hline \multirow[t]{2}{*}{ Positive revaluation } & r Pearson & $-0,124$ & 0,126 \\
\hline & Relevance & 0,073 & 0,067 \\
\hline \multirow{2}{*}{$\begin{array}{l}\text { Refraining from } \\
\text { acting }\end{array}$} & r Pearson & $-.178^{* *}$ & $.188^{* *}$ \\
\hline & Relevance & 0,010 & 0,006 \\
\hline \multirow[t]{2}{*}{ Acceptance } & r Pearson & $-0,102$ & 0,049 \\
\hline & Relevance & 0,142 & 0,484 \\
\hline \multirow[t]{2}{*}{ Focusing on emotions } & r Pearson & $-.175^{*}$ & $.160^{*}$ \\
\hline & Relevance & 0,011 & 0,020 \\
\hline \multirow[t]{2}{*}{ Denial } & r Pearson & $-.143^{*}$ & $.172^{*}$ \\
\hline & Relevance & 0,039 & 0,012 \\
\hline \multirow[t]{2}{*}{ Distraction } & r Pearson & $-0,120$ & $.205^{\star *}$ \\
\hline & Relevance & 0,084 & 0,003 \\
\hline \multirow{2}{*}{$\begin{array}{l}\text { Discontinuation of } \\
\text { activities }\end{array}$} & r Pearson & $-0,028$ & 0,004 \\
\hline & Relevance & 0,684 & 0,950 \\
\hline \multirow{2}{*}{$\begin{array}{l}\text { Use of alcohol or } \\
\text { other means }\end{array}$} & r Pearson & 0,009 & 0,021 \\
\hline & Relevance & 0,891 & 0,762 \\
\hline \multirow[t]{2}{*}{ A sense of humour } & r Pearson & $-.181^{* *}$ & 0,073 \\
\hline & Relevance & 0,008 & 0,290 \\
\hline \multirow[t]{2}{*}{ Active coping } & r Pearson & $-.174^{*}$ & $.190^{* *}$ \\
\hline & Relevance & 0,011 & 0,006 \\
\hline \multirow[t]{2}{*}{ Evasive behaviour } & r Pearson & $-.149^{*}$ & 0,134 \\
\hline & Relevance & 0,031 & 0,053 \\
\hline \multirow{2}{*}{$\begin{array}{c}\text { Seeking support and } \\
\text { concentrating on } \\
\text { emotions }\end{array}$} & r Pearson & $-.226^{* *}$ & $.160^{*}$ \\
\hline & Relevance & 0,001 & 0,020 \\
\hline
\end{tabular}

Source: own research. 


\section{DISCUSSION OF RESEARCH RESULTS AND LIMITATIONS}

The aim of the study was to check the relationship between coping with ambiguity tolerance, coping with stress, the uncertainty tolerance and the anxiety as a trait and as a condition. The hypotheses were made that uncertainty and ambiguity tolerance are strongly associated with the anxiety as a trait and weakly with anxiety as a condition; that people with a high uncertainty tolerance are good at dealing with ambiguity situations; and that people with a high uncertainty and ambiguity tolerance use different strategies for dealing with stress.

The conducted analyses allow to confirm some of the hypotheses. It turned out that to be tolerant of uncertainty and ambiguity does not coexist with anxiety as a trait and as a state, i.e., that there is no relation between the tolerance of uncertainty and ambiguity and anxiety. However, a correlation between anxiety as a state and anxiety as a trait was observed. The amount of anxiety as a trait increases with the feeling of anxiety as a state. It can be concluded that people who feel anxiety in some situations can internalize the anxiety and start to possess it as a trait. A low and negative correlation between the uncertainty tolerance and the ambiguity tolerance was also observed. This means that the greater the uncertainty tolerance of the subjects, the worse they cope with ambiguity situations.

The research also shows that after Charles S. Carver, Michael F. Scheier and Jagdish K. Weintraub (2009), people use different stress management strategies to reduce discomfort in difficult situations. The more tolerant of uncertainty, the less emotional and instrumental support and focus on emotions are used as coping strategies. In contrast, as ambiguity tolerance increases, the frequency with which distraction is used as a coping strategy increases. This means that a higher ambiguity tolerance allows you to feel less stressed. The lower the tolerance of ambiguity, the more often they use the search for emotional and instrumental support and focus on their emotions.

Please note that the analysis of the author's data is limited. 210 people took part in the study, which is a small research sample. The majority of the respondents are women (180 people). It is therefore not possible to adopt generalized results. In the qualitative sample, the survey was conducted among people with higher education or among students, which constitutes $78.2 \%$ of the total number of respondents. Most of the respondents live permanently in cities of over 150,000 residents. The surveyed sample lacked respondents living outside large cities and people with other education background. Subsequent research studies could gather a larger research sample and better fit the research work.

The suggestion is to obtain research on this issue to analyse the relationship of age or level of education with the studied variables. An interesting idea would be to investigate the correlation between the personality structure of Eysenck (1987), which covers three independent dimensions: extraversion and neuroticism and psychoticism with tolerance of uncertainty and ambiguity tolerance. 
Nevertheless, it can be determined that according to this analysis, they indicated the relationship between the tolerance of uncertainty and ambiguity with anxiety as conditions for research on indication research and gives a message to propose further actions. According to Bauman, who wrote that ambiguity, liquidity, volatility and uncertainty are words that describe the present reality (Bauman, 2007). These issues need to be addressed, e.g. in the view of the prevention and possible therapeutic activities of members of the public (Kanclerz, 2016). The knowledge of intermediary measures in the studied phenomenon may be helpful in creating support systems that would foster better psychophysical functioning of people with problems in quick adaptation to changes and the introduction of appropriate preventive programs aimed at helping these people.

\section{REFERENCES}

[1] Bauman, Z. (1995). Wieloznaczność nowoczesna, nowoczesność wieloznaczna [Modern ambiguity, modern ambiguity]. Warszawa: Wydawnictwo Naukowe PWN.

[2] Bauman, Z. (2007). Płynne czasy. Życie w epoce niepewności [Smooth times. Living in an era of uncertainty]. Warszawa: Wydawnictwo Sic!

[3] Budner, S. (1962). Intolerance of ambiguity as a personality variable. Journal of Personality, 30, 29 - 50.

[4] Carver, C. S., Scheier, M. F., \& Weintraub, J. K. (2009). Wielowymiarowy Inwentarz do Pomiaru Radzenia Sobie ze Stresem COPE [COPE Stress Management Inventory]. Warszawa: Pracownia Testów Psychologicznych Polskiego Towarzystwa Psychologicznego.

[5] Chua Chow, C., \& Sarin, R. K. (2002). Known, unknown, and unknowable uncertainties. Theory and Decision, 52(2), 27-138.

[6] Dalbert, C. (1999). Die Ungewißheitstoletanzskala: Skaleneigenschaften und Validierungsbefunde, Hallesche Berichte zur Pädagogischen Psychologie, Bericht Nr. 1. Halle (Saale): Institut für Pädagogik Martin-Luter-Universität Halle-Wittenberg.

[7] Edwards, R. W. (2003). Openness to change: Correlates and organizational consequences. Dissertation Abstracts International, Section B: The Sciences and Engineering, 63 (10-B).

[8] Endler, N. S., \& Parker, J. D. A. (1994). Assessment of multidimensional coping: Task, emotion, and avoidance strategies. Psychological Assessment, 6(1), 50-60.

[9] Eysenck, H. J. (1954). The psyhology of politics (ed. 2). New Brunswick: Transaction Publishers.

[10] Eysenck, H. J. (1987). Arousal and personality: The origins of a theory. In J. Strelau, \& H. J. Eysenck (Eds.), Personality dimensions and arousal (pp. 1-13). New York: Plenum Press.

[11] Frenkel-Brunswik E. (1949), Intolerance of Ambiguity as an Emotional and Personality Variable. Journal of Personality, 18, 108-143.

[12] Hofstede, G., \& Hofstede, G. J. (2007). Kultury i organizacje. Zaprogramowanie umystu [Cultures and organisations. Mind programming]. Warszawa: Polskie Wydawnictwo Ekonomiczne.

[13] Jacyno, M. (2007). Kultura indywidualizmu [Culture of individualism]. Warszawa: Wydawnictwo Naukowe PWN.

[14] Kahneman, D., \& Tversky, A. (1982). The psychology of preferences. Scientific American, 246(1), 60-173.

[15] Kanclerz, B. (2016). Młodzież w rzeczywistości „globalnej zmiany” z perspektywy rówieśników [Youth in the reality of "global change" from the perspective of their peers]. Kultura, spoteczeństwo, edukacja, 2(10), 281-294.

[16] Kossowska M. (2009): Nowe poznawcze wymiary osobowości o społeczne poznanie i działanie [New cognitive dimensions of personality with social cognition and action]. In: M. Kossowska, \& M. Kofta (Eds.), Psychologia poznania społecznego, Nowe tendencje (pp. 225-244). Wydawnictwo Naukowe PWN, Warszawa.

[17] Kossowska, M. (2005). Umyst niezmienny. Psychologiczne mechanizmy sztywności [The mind is unchanging. Psychological stiffness mechanisms]. Kraków: Wydawnictwo Uniwersytetu Jagiellońskiego. 
[18] Kozielecki, J. (1977). Psychologiczna teoria decyzji [Psychological decision theory]. Warszawa: Państwowe Wydawnictwo Naukowe.

[19] Lazarus, R. S. (1993). Coping theory and research: Past, present, and future. Psychosomatic Medicine, 55(3), 234-247.

[20] Majerek, B. (2018). Niepewność w społeczeństwie wspótczesnym. Studium socjopedagogiczne [Uncertainty in modern society. A sociopedagogical study]. Kraków: Oficyna Wydawnicza "Impuls".

[21] McCrae, R. R., \& Costa, P. T. (1986). Personality, Coping and Coping Effectiveness in an Adult Sampic. Jourtal of Personality, 54, 384-405.

[22] Oreg, S. (2003). Resistance to change: Developing an individual differences measure. Journal of Applied Psychology, 88(4), 680-693.

[23] Sorrentino, R. M., Hudson, G. i Huber, G. L. (2005). Umysł społeczny a style reagowania na niepewność - różnice indywidualne w kontekście interpersonalnym [The social mind and styles of responding to uncertainty - individual differences in interpersonal context]. In: W J. P. Forges, K. D. Williams, \& L. Wheeler (Eds.), Umyst społeczny. Poznawcze i motywacyjne aspekty zachowań interpersonalnych (pp. 209-236). Gdańsk: Gdańskie Wydawnictwo Psychologiczne.

[24] Studenski, R. (2004). Ryzyko i ryzykowanie [Risks and risks]. Katowice: Wydawnictwo Uniwersytetu Śląskiego.

[25] Zaleśkiewicz, T. (2005). Przyjemność czy konieczność: psychologia spostrzegania i podejmowania ryzyka [Pleasure or necessity: Psychology of perception and risk-taking]. Gdańsk: Gdańskie Wydawnictwo Psychologiczne. 